\title{
Benthic processes in fresh water fluffy sediments undergoing resuspension
}

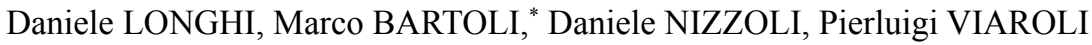 \\ Dipartmento di Bioscienze, Università di Parma, V.le G.P. Usberti 33/A, 43124 Parma, Italy. \\ *Corresponding author: marco.bartoli@unipr.it
}

\begin{abstract}
In the Po river plain relict freshwater wetlands are characterised by a low free water to emergent macrophyte surface ratio, rapid infilling and fluffy sediments, undergoing frequent resuspension. Particle mixing should alter the steep gradients of dissolved gas, nutrient and organic matter quality that generally characterise sediments, with implications for benthic processes.

Sediment features and solute fluxes were studied from December 2003 to February 2005 within the Busatello swamp complex (Northern Italy) by means of a combination of core incubation, porewater extraction and microprofiling. At the study site, along a 10 $\mathrm{cm}$ vertical profile, sediment organic matter content (32.5\%), porosity (0.94) and density (1.02 $\left.\mathrm{g} \mathrm{cm}^{-3}\right)$ were nearly constant.

Oxygen demand measured by dark core incubation (12.7-56.9 $\left.\mathrm{mmol} \mathrm{m}^{-2} \mathrm{~d}^{-1}\right)$ was strongly correlated with water temperature. Rates agreed reasonably well with diffusive oxygen fluxes calculated from microprofiles while ammonium and phosphorus regeneration rates predicted from porewater gradients (-309.3-43.4 and -0.1-0.7 $\mu \mathrm{mol} \mathrm{m}^{-2} \mathrm{~d}^{-1}$, respectively) were significantly lower than rates measured via core incubations (-129.8-5420.5 and -120.4-35.4 $\mu \mathrm{mol} \mathrm{m} \mathrm{m}^{-2} \mathrm{~d}^{-1}$, respectively). This is a probable consequence of insufficient vertical resolution of nutrient profiles and lack of steady state conditions. A sediment resuspension experiment, carried out under controlled laboratory conditions, indicated large instantaneous oxygen and nitrate consumption, a transient increase of denitrification rates and the rapid release of ammonium and soluble reactive phosphorus. In unconsolidated sediments, resuspension and mixing of sediment particles are key processes regulating mineralisation rates and benthic-pelagic coupling.
\end{abstract}

Key words: unconsolidated sediments, resuspension, porewater profiles, core incubations, oxygen demand, denitrification.

Received: April 2012. Accepted: June 2012.

\section{INTRODUCTION}

In shallow aquatic environments, processes at the sediment-water interface have a well recognised role as regulators of many solute dynamics (Emerson, 1976; den Heyer and Kalfs, 1998). Benthic aerobic respiration and chemical oxidation modulate bottom water oxygen availability and related processes (i.e., nitrification rates) and can result in the exhaustion of this electron acceptor (Froelich et al., 1979; D'Angelo and Reddy, 1994a, 1994b). Ammonium and phosphorus recycling in sediments and subsequent release to the overlying water has the potential to fuel water column primary production and maintain long-term eutrophication conditions (Blackburn and Henriksen, 1983; Mayer et al., 1999; Soto-Jimenez et al., 2003).

A considerable number of benthic flux measurements have been performed in a wide variety of nearshore marine environments (Callender and Hammond, 1982; Hopkinson and Wetzel, 1982; Archer and Devol, 1992; Rasmussen and Jorgensen, 1992; Rysgaard et al., 1995; Rabouille et al., 2003), in the open ocean (Glud et al., 1998; Jørgensen et al., 2005) and in lakes (Sweerts et al., 1991a; den Heyer and Kalfs, 1998; Liikanen et al., 2003), while, to our knowledge, only a few studies were carried out in fluffy sediments of freshwater wetlands (Jensen and Andersen,
1992; Reddy et al., 1996; Mayer et al., 1999; Fisher and Reddy, 2001; Longhi et al., 2008). Here, oxygen dynamics and nutrient regeneration rates are strictly coupled and affect a variety of wetland functions and processes, such as primary production, greenhouse gas emission and the sedimentary accumulation of organic matter (Longhi et al., 2008; Pierobon et al., 2010). Uncoupling between high sedimentation of organic matter and mineralisation rates determines the burial of refractory material, the accumulation of fluffy sediments and ultimately the shift from shallow aquatic environments towards terrestrial ecosystems. Detailed knowledge of decomposition rates and nutrient recycling in these systems can thus provide helpful information for management purposes (Godshalk and Wetzel, 1978; Reddy and D'Angelo, 1994).

In consolidated sediments, benthic solute exchange is regulated by abiotic and biotic factors such as concentration gradients, sediment tortuosity, microbial and benthic microalgal activities, burrowing, ventilation or excretion activities by macrofauna (Aller, 1980; Berner, 1980; Blackburn and Henriksen, 1983; van Der Loeff et al., 1984; Kristensen, 1985; Sundback et al., 1991; Sweerts et al., 1991a; Rizzo et al., 1992; Rysgaard et al., 1995). Instead, in unconsolidated sediments, solute transfer across the sediment water interface may be strongly influenced also by 
resuspension of sediment particles induced by wind, bioturbation by large fishes and methane ebullition (Breukelaar et al., 1994; Liikanen et al., 2003; Haeckel et al., 2007).

Different methods were used to determine the magnitude and direction of solute fluxes across the sediment water interface: in situ incubation of benthic chambers (Rowe et al., 1975; Callender and Hammond, 1982; Hopkinson and Wetzel, 1982; van Der Loeff et al., 1984), laboratory incubation of intact sediment cores (Rasmussen and Jorgensen, 1992; Moore et al., 1998) and extraction or microsensor profiling of porewaters coupled to deterministic models of solute flux, such as Fick's laws of diffusion (Berner, 1980; Klump and Martens, 1981; Sweerts et al., 1991a; Berg et al., 1998). The results from these approaches to flux measurement are often compared in order to obtain some estimate of the variability between the techniques, and in the attempt to determine the most appropriate experimental approach for a given system.

In this study we evaluated dark oxygen demand and ammonium and phosphorus regeneration rates over a oneyear period by means of intact core incubation, microprofiling and porewater extraction in unconsolidated wetland sediments. We also simulated sediment resuspension and evaluated its effect on oxygen demand, denitrification rates and nutrient fluxes. The investigation had a threefold aim: i) analyse the seasonal evolution of benthic mineralization rates in relation to water temperature, ii) analyse the effect of sediment resuspension and iii) compare re- sults obtained with different commonly used techniques for quantifying benthic processes.

We hypothesise that in unconsolidated sediments transient episodes of resuspension and particle mixing i) enhance nutrient regeneration and promote the mineralisation of organic matter and ii) set frequently to zero solute gradients and impede steady state conditions of the benthic system.

\section{METHODS}

\section{Study area}

This study was conducted from December 2003 to February 2005 in the Natural Reserve Paludi del Busatello, an 81 ha wetland complex located in between the provinces of Mantua and Verona, Northern Italy (Fig. 1). This marsh is a residual area of a vast wetland system that was almost entirely converted into agricultural land in the last decades.

Most of the surface is colonized by reed stands (67 ha); the former Busatello river (which is now a narrow shallow channel with almost stagnant water) divides the Reserve in two areas having approximately the same surface; besides the Busatello river, the marsh hosts a network of ponds. The wetland environment is undergoing rapid burial due to accumulation of refractory organic matter and active management is required to protect the relevant aquatic species as the turtle Emys orbicularis, the

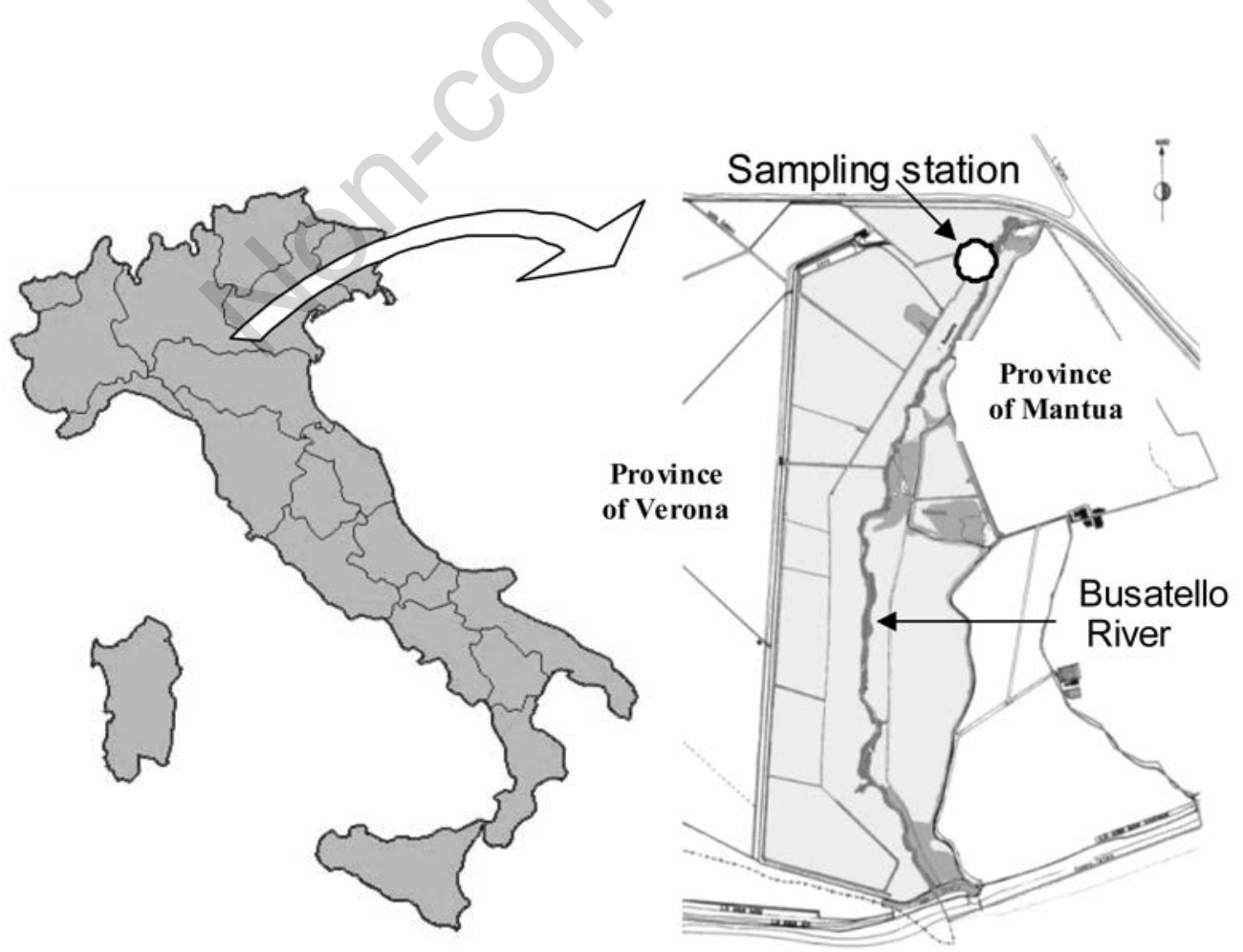

Fig. 1. Map of the Natural Reserve Paludi del Busatello with the indication of the sampling station. 
endemic frog Rana latastei, a number of floating leaved and submersed macrophytes and, among the autochthonous fish, the pike Esox lucius.

Dominant macrophyte communities consist of the common reed Phragmites australis, sedges as Carex riparia, floating leaved plants as Nuphar luteum and Nymphaea alba and submersed plants as Ceratophyllum demersum, Utricularia australis, Myriophyllum spicatum and Najas marina. The site chosen for this study is located in the northern and more preserved part of the Reserve (Fig. 1), where the Busatello river enlarges and forms a pond which is devoid of macrophytic vegetation. Chlorophyll $a$ (Chl $a$ ) generally peaks in winter $\left(\sim 20 \mu \mathrm{g} \mathrm{L}^{-1}\right)$, while it is very low during summer months, resulting in transparent waters. Summer months are also generally characterised by low nutrient concentrations (dissolved inorganic nitrogen, $\mathrm{DIN}<25 \mu \mathrm{M}$, soluble reactive phosphorous, $\mathrm{SRP}<0.1 \mu \mathrm{M}$ ). Water depth is $1 \mathrm{~m}$, sediments are fluffy and poor of macrofauna.

\section{Sampling}

Water and sediment samples were collected on $10^{\text {th }}$ December 2003, $16^{\text {th }}$ March, $21^{\text {st }}$ July and $16^{\text {th }}$ September 2004 , and $23^{\text {rd }}$ February 2005. On each date, water column temperature, $\mathrm{pH}$, conductivity and dissolved oxygen concentrations were measured in situ with a multiple probe (ISI Instruments, model 556, Twin lakes, WI, USA) while DIN, SRP and Chl $a$ concentrations were analysed in the laboratory with standard spectrophotometric methods (Koroleff, 1970; Valderrama, 1977; A.P.H.A., 1981). Six intact sediment cores were collected by hand using transparent Plexiglas ${ }^{\circledR}$ liners, and $\sim 100 \mathrm{~L}$ of water were collected for core maintenance during transport, preincubation and incubation periods. Three cores (i.d. 20 $\mathrm{cm}$, height $40 \mathrm{~cm}$ ) were collected for flux measurements via dark laboratory incubation and 3 cores (i.d. $8 \mathrm{~cm}$, height $40 \mathrm{~cm}$ ) for sediment microprofiling and porewater characterisation by slicing and squeezing. In September 2004, 12 additional cores (i.d. $8 \mathrm{~cm}$, height $40 \mathrm{~cm}$ ) were collected for a sediment resuspension experiment; six cores were used for flux measurements and six for the determination of denitrification rates (see later).

After sampling, sediment level inside collected liners was adjusted to $20 \mathrm{~cm}$ leaving an overlying water column of about $10 \mathrm{~cm}$. Cores were sealed in the bottom with rubber bungs and stored with the top open submersed in a box with cooled pond water. Within 4 hours from sampling, cores were transferred in a large tank containing aerated pond water at ambient temperature and left overnight. Water mixing inside cores was ensured with small pumps (20 cm i.d. cores) or Teflon ${ }^{\circledR}$-coated magnetic bar suspended above the sediment interface and driven by an external motor ( $8 \mathrm{~cm}$ i.d. cores); water stirring was on during the whole preincubation and incubation periods.

\section{Sediment characterisation and profiling}

The day after the sampling, $\mathrm{O}_{2}, \mathrm{pH}$ and redox potential (Eh) profiles were measured in triplicate in each core by means of micro and minisensors. $\mathrm{O}_{2}$ and Eh profiles were done using microsensors with a $50 \mu \mathrm{m}$ tip and a response time of $\sim 0.3$ and $\sim 30 \mathrm{~s}$, respectively (Unisense, Aarhus, Denmark). A saturated calomel electrode was used as reference sensor for Eh measurements (Radiometer, Brønshøj, Denmark). Profiles of $\mathrm{pH}$ were done using mini electrodes with tip $1 \mathrm{~mm}$ and response time of $\sim 30 \mathrm{~s}$ (Diamond General, Ann Arbor, MI, USA). All sensors were mounted on a manual micromanipulator (vertical resolution $0.01 \mathrm{~mm}$, Tesa Hite, Switzerland). Profiles had different vertical resolutions depending upon the parameter, the season and the diameter of the sensor. In particular, vertical resolution of oxygen profiles varied from 0.2 (July and September 2004) to $0.5 \mathrm{~mm}$ (December 2003, March 2004 and February 2005), while vertical resolution of Eh and $\mathrm{pH}$ profiles was $2 \mathrm{~mm}$ at each sampling date. The water-sediment interface was recognised as the layer with the steeper $\mathrm{O}_{2}$ drop (Revsbech, 1983); $\mathrm{O}_{2}$ profiles were limited to the oxic horizon, while $\mathrm{pH}$ and Eh profiles were conducted over the upper two sediment centimetres.

Immediately after profiling, the cores were extruded and sediments were sliced into $0-1,1-2,2-3,3-5$ and 5$10 \mathrm{~cm}$ intervals for density, porosity, water, organic matter, total $\mathrm{C}, \mathrm{N}$ and $\mathrm{P}$ content determination and for porewater characterization $\left(\mathrm{NH}_{4}{ }^{+}\right.$and SRP); interstitial water was obtained by squeezing the slices under $\mathrm{N}_{2}$ atmosphere.

Sediment density was determined by weighing $5 \mathrm{~cm}^{3}$ of homogenised fresh sediment into pre-weighed ceramic dishes. The samples were then dried at $60^{\circ} \mathrm{C}$ to constant weight and reweighed to determine sediment porosity $\left(\mathrm{mL} \mathrm{H}_{2} \mathrm{O} \mathrm{mL} \mathrm{sed}{ }^{-1}\right)$ and water percentage as weight loss. Organic matter content (loss on ignition, LOI) was evaluated from weight loss after ignition of dried and powdered sediment $(\sim 0.1 \mathrm{~g})$ at $400^{\circ} \mathrm{C}$ for 3 hours. Dried sediments were also analysed for organic $\mathrm{C}$ and total $\mathrm{N}$ content (CHNS-O EA 1108, Carlo Erba Elemental Analyzer, Milano, Italy) and total $\mathrm{P}$ content according to Aspila et al. (1976).

Calculation of the diffusive fluxes of $\mathrm{O}_{2}, \mathrm{NH}_{4}{ }^{+}$and SRP across the sediment-water interface was based on application of Fick's law to the concentration profiles as described by Berner (1980):

$$
J=\frac{\delta C}{\delta z} \cdot D
$$

where $J\left(\mu \mathrm{mol} \mathrm{m}{ }^{-2} \mathrm{~h}^{-1}\right)$ is the flux, $D\left(\mathrm{~cm}^{2} \mathrm{~s}^{-1}\right)$ is the diffusion coefficient and $\delta C / \delta z\left(\mu \mathrm{M} \mathrm{cm}^{-1}\right)$ is the concentration gradient. Molecules and ions diffuse according to the parameter $D$ only in the water column and in the diffusive 
boundary layer; within the sediments, $D$ is generally corrected for tortuosity using the porosity and porosity-tortuosity relationship (Sweerts et al., 1991a):

$$
D s=\phi^{m} \cdot D
$$

where $D s$ is the diffusion within sediments, $\phi$ is the sediment porosity and $m$ is an empirical factor depending on sediment features.

For $\mathrm{O}_{2}$ flux calculations we used the average porosity values relative to the upper sediment layer, while for $\mathrm{NH}_{4}{ }^{+}$ and SRP fluxes we used the average porosity calculated along the $0-10 \mathrm{~cm}$ horizon; for $m$ we assumed a value of 1 as was done by other authors working with very soft freshwater sediments (Urban et al., 1997). Diffusion coefficients were taken from Broecker and Peng (1974) and Li and Gregory (1974) and corrected for water temperature according to Li and Gregory (1974).

\section{Estimation of sedimentation rates}

Gross sedimentation rates were evaluated in March and September 2004 by means of cylindrical sediment traps, consisting of Plexiglas ${ }^{\circledR}$ liners (i.d. $5 \mathrm{~cm}$, height 30 cm) (Bloesch and Burns, 1980). For each date, six traps were randomly placed on the bottom of the sampling station and retrieved after 23 (March) and after 15 days (September). Longer deployment in March coincided with minimum water temperatures and sedimentation rates and was set in order to accumulate enough material for reliable estimate of rates. We acknowledge that long traps deployment can lead to slight underestimate of sedimentation rate, but in this specific case microbial activity was limited by low water temperatures and by the quality of the organic matter. September exposure time overlapped that suggested by Bloesch and Burns (1980).

In the laboratory the trap contents were dried at $60^{\circ} \mathrm{C}$ and weighed. The sedimentation rate $\left(\mathrm{g} \mathrm{m}^{-2} \mathrm{~d}^{-1}\right)$ was calculated as the dry mass of sediment accumulated normalised by the area of the trap and divided by the number of days that the trap was deployed.

\section{Sediment core incubations}

The day after sampling, cores were incubated in the dark for the determination of $\mathrm{O}_{2}, \mathrm{NH}_{4}{ }^{+}$and SRP net fluxes. The morning after the sampling, water inside incubation tank and inside cores was replaced with fresh water. The incubation started just after, when floating Plexiglas ${ }^{\circledR}$ lids were positioned on the top of each core. Employed lids were perfectly fitting the inner core wall, minimising any significant gas exchange with the atmosphere during the incubation. At the beginning of the incubation, water samples were collected with a plastic syringe from the tank and then, at different time intervals, from a valve on the top lids. Each time $\sim 100 \mathrm{~mL}$ were collected; samples for $\mathrm{O}_{2}$ analyses were immediately transferred into $12 \mathrm{~mL}$ glass tubes (Exetainers, Labco, Lampeter, UK) and analysed by Winkler titration (A.P.H.A., 1981). Samples for nutrient analyses were filtered (pore size $0.7 \mu \mathrm{m}, \mathrm{GF} / \mathrm{F}$ Whatman filters, Whatman International Ltd, Maidstone, Kent, UK) and transferred into glass tubes for SRP determination or frozen in plastic vials for $\mathrm{NH}_{4}^{+}$analysis, as previously described. Total incubation time was comprised between two (July) and five (February) hours; fluxes were determined according to the following equation:

$$
F x=\alpha \cdot h \cdot 10
$$

where $F x\left(\mu \mathrm{mol} \mathrm{m}^{-2} \mathrm{~h}^{-1}\right)$ is the flux of the $x$ species, $\alpha(\mu \mathrm{M}$ $\left.\mathrm{h}^{-1}\right)$ is the slope of the linear regression between concentration of the $x$ species and incubation time, $h(\mathrm{~cm})$ is the height of the overlying water column and 10 is a factor necessary to convert units.

\section{Sediment resuspension experiment}

In September 2004, 12 cores were collected for two sediment resuspension experiments, one for the measurement of oxygen and nutrient fluxes ( 6 cores) and one for denitrification (6 cores).

\section{Flux measurements}

Three cores were left untreated (C), while the sediment of three cores (upper $10 \mathrm{~cm}$ ) was gently resuspended in the water column by means of a trowel to simulate a resuspension event (Mix). In Mix cores, samples of water overlying sediment were collected before and after sediment mixing, when particles were settled, and analysed for dissolved oxygen, $\mathrm{NH}_{4}{ }^{+}, \mathrm{NO}_{3}{ }^{-}$and SRP concentrations. After water sampling, the water overlying sediments in Mix cores was carefully replaced with in situ water and thereafter $\mathrm{C}$ and Mix cores were incubated for the determination of $\mathrm{O}_{2}, \mathrm{NH}_{4}{ }^{+}, \mathrm{NO}_{3}{ }^{-}$and SRP fluxes, according to the procedure previously described. We replaced the water overlying sediments as resuspension releases pore water solutes that deeply alter the chemistry of the core water. This has implication for gradients that do not reflect what happens in the natural environment. Here, released solutes are diluted in a large water volume and concentrations do not change appreciably. Our intention was to measure processes driven by porewater and sediment features altered by a short term resuspension event and for this reason we replaced overlying water with in situ water.

\section{Denitrification measurement}

${ }^{15} \mathrm{NO}_{3}^{-}$was added to the water column of the second set of 6 cores to increase the nitrate pool by $\sim 30 \%$ and then three cores were mixed as previously described (Mix_Den), 
while the other three were used as a control (C Den). The $\mathrm{NO}_{3}{ }^{-}$concentration was measured prior to the addition of ${ }^{15} \mathrm{NO}_{3}^{-}$and before the cores were mixed in order to calculate the ${ }^{14} \mathrm{~N} /{ }^{15} \mathrm{~N}$ ratio in the $\mathrm{NO}_{3}{ }^{-}$pool. Floating lids were then positioned on the top of all cores and the incubation was carried out, according to standard procedures (Dalsgaard et al., 2000). At the end of the incubation, $10 \mathrm{~mL}$ of $7 \mathrm{M} \mathrm{ZnCl}_{2}$ were added to the water phase of all cores and then sediment and water were mixed. Part of the slurry was then transferred into $12.5 \mathrm{~mL}$ gas-tight vials; ${ }^{14} \mathrm{~N}^{15} \mathrm{~N}$ and ${ }^{15} \mathrm{~N}^{15} \mathrm{~N}$ abundance in $\mathrm{N}_{2}$ was analysed by mass spectrometry at the National Environmental Research Agency (Silkeborg, Denmark). The rates of denitrification $\left(D_{\text {tot }}\right)$ were calculated according to the equations and assumptions of Nielsen (1992): $\quad D 15=p\left({ }^{15} \mathrm{~N}^{14} \mathrm{~N}\right)+2 \mathrm{p}\left({ }^{15} \mathrm{~N}^{15} \mathrm{~N}\right) \quad$ and D14 $=p\left({ }^{15} \mathrm{~N}^{14} \mathrm{~N}\right)+2 \mathrm{p}\left({ }^{14} \mathrm{~N}^{14} \mathrm{~N}\right)$, where D15 and D14=rates of denitrification based on ${ }^{15} \mathrm{NO}_{3}^{-}$and ${ }^{14} \mathrm{NO}_{3}^{-}$, respectively; and $p\left({ }^{14} \mathrm{~N}^{14} \mathrm{~N}\right), \mathrm{p}\left({ }^{15} \mathrm{~N}^{14} \mathrm{~N}\right)$ and $\mathrm{p}\left({ }^{15} \mathrm{~N}^{15} \mathrm{~N}\right)=$ rates of production of labelled and unlabelled $\mathrm{N}_{2}$ species. Because the $p\left({ }^{14} \mathrm{~N}^{14} \mathrm{~N}\right)$ cannot be readily measured, estimation of D14 was obtained from: D14=D15 x $p\left({ }^{15} \mathrm{~N}^{14} \mathrm{~N}\right) / 2 \mathrm{p}\left({ }^{15} \mathrm{~N}^{15} \mathrm{~N}\right)$.

\section{RESULTS}

\section{Water column characterisation}

In the period of the investigation, temperatures ranged between 3.0 and $23.5^{\circ} \mathrm{C}$; $\mathrm{pH}$ was alkaline (7.83-7.98) and oxygen saturation was minimum in March $(\sim 61 \%)$ and maximum in December 2003 and February $2005(\sim 83 \%)$, with an average value of $76 \pm 10 \%$ (Tab. 1). DIN concentration peaked in winter $(160-260 \mu \mathrm{M})$ and was minimum in summer $\left(<25 \mu \mathrm{M}\right.$ in July 2004); $\mathrm{NO}_{\mathrm{x}}^{-}$was generally the dominant form of inorganic nitrogen, except in July 2004. SRP concentration was similar in March and July 2004 and peaked in December 2003 and February 2005. Chl $a$ concentrations were low in summer $\left(\sim 6 \mu \mathrm{g} \mathrm{L}^{-1}\right.$ in July 2004) and relatively high in winter $\left(21.8 \mu \mathrm{g} \mathrm{L}^{-1}\right.$ in December 2003).

\section{Sediment characterisation and sedimentation rates}

Surface sediments were fluffy and consisting of macrophyte fragments; the colour was light brown with no apparent vertical discontinuities. The macrofauna community was poor with large individuals of the bivalve $A n$ odonta sp. (not sampled in the cores used in this work) and a few chironomids. Many cores were discarded during sampling activities due to large bubbles breaking the sediment-water interface and resuspending particles; ebullition was evident also in situ.

Density, porosity, water and organic matter content and elemental composition were homogeneous between analysed slices along the $0-10 \mathrm{~cm}$ horizon at all sampling dates (ANOVA, $\mathrm{P}>0.05$ ). Sediment density (1.01-1.03 g $\mathrm{cm}^{-3}$ ) was close to that of water and not significantly different among seasons (ANOVA, $\mathrm{P}>0.05$ ); water content was always above $91 \%$ and sediment porosity above 0.86 (Tab. 2). Organic matter content tended to be higher in July and September 2004 (33.4 \pm 1.7 and 34.4 $\pm 1.6 \%$, respectively) and lower in December 2003 (31.0土1.4\%), with an average value of $32.5 \pm 1.8 \%$ along the $0-10 \mathrm{~cm}$ horizon. Average values of organic $\mathrm{C}$, total $\mathrm{N}$ and $\mathrm{P}$ were $17.43 \pm 0.88,1.86 \pm 0.12$ and $0.15 \pm 0.02 \%(\mathrm{w} / \mathrm{w})$, respectively, and did not show seasonal trends (Tab. 2).

Gross sedimentation rates were similar on the two sampling dates when this process was measured, with average values of $37.7 \pm 7.0$ and $44.8 \pm 5.4 \mathrm{~g}_{\mathrm{dw}} \mathrm{m}^{-2} \mathrm{~d}^{-1}$ calculated for March and September 2004, respectively.

\section{Sediment profiles of oxygen, redox potential, $\mathrm{pH}$, ammonium and soluble reactive phosphorous}

Porewater $\mathrm{O}_{2}$ and Eh values exhibited small scale sharp vertical variations. The thickness of the oxic sediment layer varied with seasons with highest values $(\sim 7 \mathrm{~mm})$ measured in winter, and minimum ( $<2 \mathrm{~mm}$ ) in summer (Fig. 2). Oxygen penetration was inversely correlated with both water temperature $\left(\mathrm{r}^{2}=0.96, \mathrm{P}<0.001\right)$ and organic matter content $\left(\mathrm{r}^{2}=0.92, \mathrm{P}<0.001\right)$. All profiles showed typical parabolafitting depth trends indicating that the oxygen distribution was mostly governed by molecular diffusion between the oxic water and the oxygen-consuming sediment. None of the oxygen microprofiles showed subsurface peaks.

Water column Eh was always largely positive ( $>200$ $\mathrm{mV})$ with the exception of July $(\sim 50 \mathrm{mV})$. Sharp reduction in the Eh values was measured in all sampling dates within

Tab. 1. Physicochemical parameters of the water overlying sediments at the sampling station.

\begin{tabular}{lccccccccc}
\hline Date & $\begin{array}{c}\mathrm{T} \\
\left({ }^{\circ} \mathrm{C}\right)\end{array}$ & $\mathrm{pH}$ & $\begin{array}{c}\text { Conductivity } \\
\left(\mu \mathrm{S} \mathrm{cm}^{-1}\right)\end{array}$ & $\begin{array}{c}\mathrm{O}_{2} \\
(\mu \mathrm{M})\end{array}$ & $\begin{array}{c}\mathrm{O}_{2} \\
(\%)\end{array}$ & $\begin{array}{c}\mathrm{NH}_{4}^{+} \\
(\mu \mathrm{M})\end{array}$ & $\begin{array}{c}\mathrm{NOx}^{-} \\
(\mu \mathrm{M})\end{array}$ & $\begin{array}{c}\mathrm{SRP} \\
(\mu \mathrm{M})\end{array}$ & $\begin{array}{c}\mathrm{Chl}^{+} a \\
\left(\mu \mathrm{g} \mathrm{L} \mathrm{L}^{-1}\right)\end{array}$ \\
\hline $12 / 03$ & 3.0 & 7.86 & 409 & 334 & 83.1 & 9.8 & 149.1 & 0.36 \\
$03 / 04$ & 8.0 & 7.91 & 497 & 222 & 60.8 & 6.2 & 78.6 & 0.09 \\
$07 / 04$ & 23.0 & 7.98 & 545 & 206 & 74.8 & 15.1 & 8.5 & 0.09 \\
$09 / 04$ & 23.5 & 7.83 & 303 & 208 & 78.9 & 7.0 & 60.0 & 0.00 \\
$02 / 05$ & 4.0 & 7.95 & 639 & 319 & 83.3 & 15.3 & 245.0 & 0.40 \\
\hline
\end{tabular}

SRP, soluble reactive phosphorous; Chl a, Chlorophyll a. 
the upper $5 \mathrm{~mm}$; below this horizon Eh was constant with depth and close to $-300 \mathrm{mV}$. The redox potential discontinuity was quite overlapping the oxic-anoxic interface at all sampling dates with up to $500 \mathrm{mV}$ drop (from +200 to -300 $\mathrm{mV}$ ) measured in September 2004 (Fig. 2).

Porewater $\mathrm{pH}$ was generally slightly lower compared to that of the water column; maximum variations were measured in summer with a decrease of approximately 0.7 units in the $0-0.5 \mathrm{~cm}$ upper layer (from 7.8 to 7.1, July 2004). Minimum porewater $\mathrm{pH}$ values were slightly below 7 (6.7, July 2004); on the other dates values were rather constant and close to 7.5 (Fig. 2).

Porewater concentrations of $\mathrm{NH}_{4}^{+}$and SRP generally increased with depth at all sampling dates (Fig. 3). During the entire study, $\mathrm{NH}_{4}{ }^{+}$concentrations in the upper $0-2 \mathrm{~cm}$ sediment layer were comparable to those measured in the water column $(2-10 \mu \mathrm{M})$ and increased in the $2-3 \mathrm{~cm}$ layer; in the deepest investigated horizon $(5-10 \mathrm{~cm}) \mathrm{am}-$ monium levels were surprisingly high in December 2003 $(554 \pm 246 \mu \mathrm{M})$. During $2004, \mathrm{NH}_{4}^{+}$concentrations in the deepest slice peaked in July $(386 \pm 119 \mu \mathrm{M})$, while minimum values were recorded in March and September $(\sim 100$ and $\sim 180 \mu \mathrm{M})$.

Despite the anoxic conditions and low Eh, porewater SRP concentrations were extremely low in the upper $5 \mathrm{~cm}$ horizon and very similar to those of the overlying water on four out of the five sampling dates, with values varying between 0.1 and $1.9 \mu \mathrm{M}$. The exception was December 2003 when SRP concentrations increased significantly with depth and peaked in the $5-10 \mathrm{~cm}$ slice $(37 \pm 29 \mu \mathrm{M})$. Values measured in the deepest slice were close to $10 \mu \mathrm{M}$ in March and July 2004 and below $5 \mu \mathrm{M}$ in September 2004 and February 2005 (Fig. 3).

\section{Oxygen, ammonium, and soluble reactive phosphorous benthic fluxes}

Oxygen uptake by sediments was mostly regulated by water temperature, with highest rates determined in July (56.9 \pm 5.0 and $42.9 \pm 6.2 \mathrm{mmol} \mathrm{m}^{-2} \mathrm{~d}^{-1}$ for total and diffusive uptake, respectively) and in September 2004 (56.9 \pm 23.7 and $48.1 \pm 10.3 \mathrm{mmol} \mathrm{m}^{-2} \mathrm{~d}^{-1}$ for total and diffusive uptake, respectively), and lowest rates measured in December 2003 (12.7 \pm 4.2 and $3.8 \pm 1.3 \mathrm{mmol} \mathrm{m}^{-2} \mathrm{~d}^{-1}$ for total and diffusive uptake, respectively) (Fig. 4). The largest difference between measured and calculated oxygen fluxes was during winter months when the diffusive flux accounted for only 25 to $30 \%$ of the total sediment oxygen demand. On the contrary, in September and July 2004 diffusive uptake accounted for 75 to $84 \%$ of total oxygen uptake.

Sediments regenerated $\mathrm{NH}_{4}{ }^{+}$to the water column on four out of the five sampling dates, with rates increasing from December $2003\left(\sim 200 \mu \mathrm{mol} \mathrm{m}^{-2} \mathrm{~d}^{-1}\right)$ to September $2004\left(\sim 5400 \mu \mathrm{mol} \mathrm{m}^{-2} \mathrm{~d}^{-1}\right)$. Only in February 2005 a net $\mathrm{NH}_{4}{ }^{+}$uptake (-130 $\left.\mu \mathrm{mol} \mathrm{m}^{-2} \mathrm{~d}^{-1}\right)$ was measured (Fig. 5). As for oxygen demand, the seasonal evolution of $\mathrm{NH}_{4}{ }^{+}$ fluxes was temperature dependent. Instead, SRP fluxes were erratic and did not follow a clear seasonal pattern, increasing from December 2003 to July 2004 but shifting to negative in September 2004 (Fig. 5).

Calculated diffusive $\mathrm{NH}_{4}{ }^{+}$and SRP fluxes were always positive and varied between $124 \pm 25 \mu \mathrm{mol} \mathrm{m}^{-2} \mathrm{~d}^{-1}$ (March 2004) and $784 \pm 236 \mu \mathrm{mol} \mathrm{m}^{-2} \mathrm{~d}^{-1}$ (July 2004) and between 1.4 (February 2005) and $17.5 \mu \mathrm{mol} \mathrm{m}{ }^{-2} \mathrm{~d}^{-1}$ (December 2003), respectively, without any seasonal trend.

\section{Sediment resuspension, benthic fluxes and denitrification rates}

Resuspension of surface sediments resulted in a sudden drop of oxygen and nitrate concentrations into the overlying water and in ammonium and reactive phosphorus release. Average oxygen concentration in the water column decreased from 0.29 to $0.07 \mathrm{mM}$, corresponding to an instantaneous $\mathrm{O}_{2}$ consumption of $28.2 \pm 0.3 \mathrm{mmol} \mathrm{m}^{-2}$. Similarly, nitrate concentration decreased from 34.5 to 10.5 $\mu \mathrm{M}$, with a nitrate consumption of $3.13 \pm 0.43 \mathrm{mmol} \mathrm{m}^{-2}$. Ammonium concentration in the water overlying sediments increased during resuspension from 11.0 to 63.7103.0 $\mu \mathrm{M}$, while water column SRP level increased from 0.20 to $0.25-0.83 \mu \mathrm{M}$. $\mathrm{NH}_{4}{ }^{+}$and SRP release during sediment resuspension was equivalent to an efflux varying between 7.4 and $12.0 \mathrm{mmol} \mathrm{m}^{-2}$ and from 6.4 and $82.4 \mu \mathrm{mol}$ $\mathrm{m}^{-2}$, respectively.

Tab. 2. Main features of sediments at sampling station. As values of measured parameters were homogeneous in the considered vertical horizon (0-10 cm depth) data from the different layers were pooled. Average values $\pm \mathrm{SD}(\mathrm{n}=15)$ are reported.

\begin{tabular}{|c|c|c|c|c|c|c|c|}
\hline Date & $\begin{array}{c}\text { Water } \\
\text { content }(\%)\end{array}$ & $\begin{array}{l}\text { Density } \\
\left(\mathrm{g} \mathrm{cm}^{-3}\right)\end{array}$ & Porosity & $\begin{array}{c}\text { Organic } \\
\text { matter }(\%)\end{array}$ & $\begin{array}{c}\text { Organic } \\
\text { carbon }(\%)\end{array}$ & $\begin{array}{c}\text { Total } \\
\text { nitrogen }(\%)\end{array}$ & $\begin{array}{c}\text { Total } \\
\text { phosphorus }(\%)\end{array}$ \\
\hline $12 / 03$ & $93.3 \pm 1.0$ & $1.02 \pm 0.02$ & $0.95 \pm 0.01$ & $31.0 \pm 1.4$ & $17.18 \pm 1.03$ & $1.79 \pm 0.08$ & $0.13 \pm 0.01$ \\
\hline $03 / 04$ & $93.7 \pm 1.2$ & $1.01 \pm 0.04$ & $0.95 \pm 0.03$ & $31.8 \pm 1.2$ & $17.20 \pm 0.82$ & $1.87 \pm 0.07$ & $0.17 \pm 0.01$ \\
\hline $07 / 04$ & $92.5 \pm 1.4$ & $1.03 \pm 0.11$ & $0.95 \pm 0.09$ & $33.4 \pm 1.7$ & $17.25 \pm 0.84$ & $1.84 \pm 0.09$ & $0.14 \pm 0.01$ \\
\hline $09 / 04$ & $93.3 \pm 1.0$ & $1.02 \pm 0.02$ & $0.95 \pm 0.02$ & $34.4 \pm 1.6$ & $17.86 \pm 0.65$ & $1.88 \pm 0.21$ & $0.14 \pm 0.01$ \\
\hline $02 / 05$ & $92.4 \pm 1.0$ & $1.01 \pm 0.02$ & $0.91 \pm 0.02$ & $32.1 \pm 1.0$ & $17.64 \pm 0.94$ & $1.92 \pm 0.08$ & $0.16 \pm 0.01$ \\
\hline
\end{tabular}


Sediment-water fluxes of $\mathrm{O}_{2}, \mathrm{NH}_{4}{ }^{+}$and SRP measured after sediment mixing and renewal of water overlying sediments were not statistically different from those measured in control cores (ANOVA, $\mathrm{P}>0.05$ ) and comparable with those found in September (Fig. 6). There was just a tendency towards decreasing rates of oxygen uptake and ammonium release in mixed compared to control cores. Nitrate fluxes were negative in both control and mixed cores, with a tendency towards higher consumption rates in control cores $(-1.78$ to $\left.14.96 \mathrm{mmol} \mathrm{m}^{-2} \mathrm{~d}^{-1}\right)$ than in mixed cores (-1.66 to -3.54 mmol m$\left.{ }^{-2} \mathrm{~d}^{-1}\right)$.

Denitrification rates measured in resuspended sediments (12.40-19.80 $\left.\mathrm{mmol} \mathrm{m}^{-2} \mathrm{~d}^{-1}\right)$ were significantly higher (ANOVA, $\mathrm{P}<0.05$ ) than rates measured in control cores $\left(0.33-1.34 \mathrm{mmol} \mathrm{m}^{-2} \mathrm{~d}^{-1}\right)$ (Fig. 6).

$\mathrm{O}_{2}(\mu \mathrm{M})$
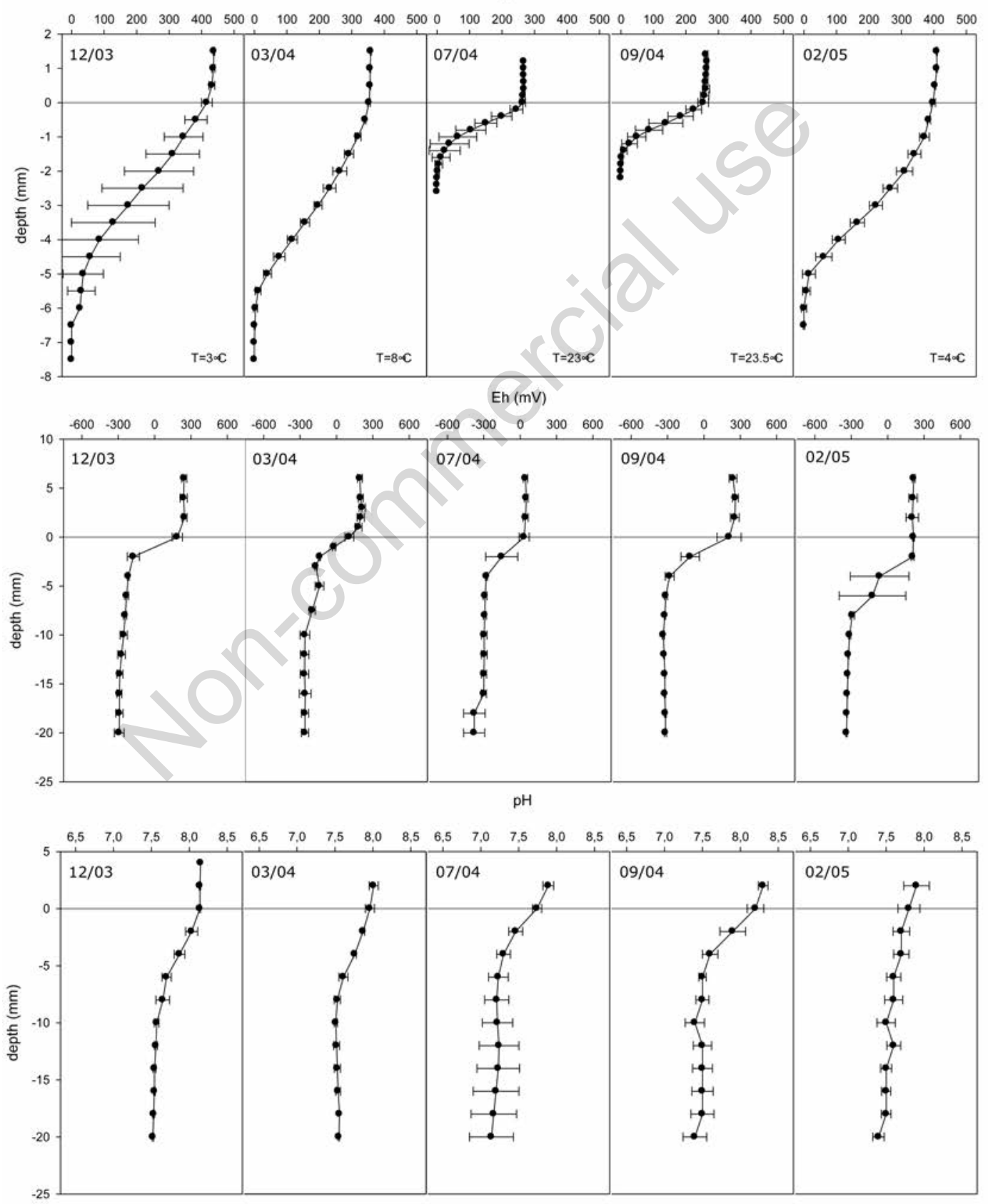

Fig. 2. Seasonal sediment profiles of dissolved oxygen, $\mathrm{pH}$ and Eh measured at sampling station via micro and mini sensors. Average values $\pm \mathrm{SD}(\mathrm{n}=3)$ are reported. 


\section{DISCUSSION}

\section{Vertical profiles in unconsolidated sediments}

Gross sedimentation at sampling station is comparable to that reported for shallow lakes exhibiting high rates of sediment resuspension (Niemisto et al., 2008; Nurminen and Horppila, 2009). Sediment resuspension is recognised as an important physical process affecting a number of ecological aspects of shallow water bodies (Evans, 1994; Scheffer, 1998) and accounts for $40-90 \%$ of total sedimentation rates (Jimenez-Montealegre et al., 2002; Niemisto et al., 2008). If this is true also at our sampling site, net sedimentation rate at the study area can be estimated to be $4-25 \mathrm{~g}_{\mathrm{dw}} \mathrm{m}^{-2} \mathrm{~d}^{-1}$, which is equivalent to a deposition of fresh organic matter of $2-13 \mathrm{~cm} \mathrm{y}^{-1}$. This ultimately means that the sediment layer characterised in the present study was very recent.

In the shallow study area, sediment density along the upper $0-10 \mathrm{~cm}$ horizon was very close to that of water. Winds or benthic fish such as carps, abundant in the study area, can easily resuspend, mix and homogenise settled particles (Sondergaard et al., 1992; Breukelaar et al., 1994; Cline et al., 1994; Mayer et al., 1999; Persson and Svensson, 2006). An evidence of this phenomenon is given by

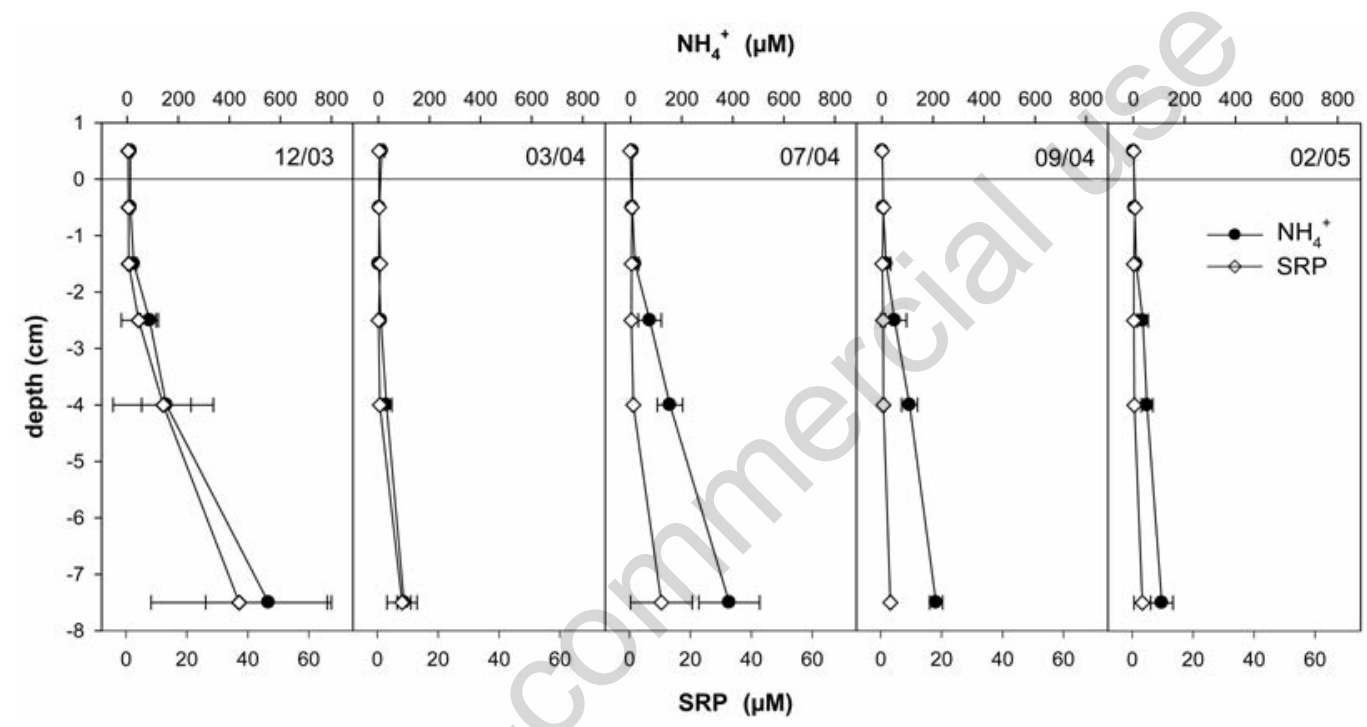

Fig. 3. Depth profiles of ammonium $\left(\mathrm{NH}_{4}^{+}\right)$and soluble reactive phosphorous (SRP) concentration within sediments; results from the whole investigation cycle are shown. For each profile average values $\pm \operatorname{SD}(n=3)$ are reported.

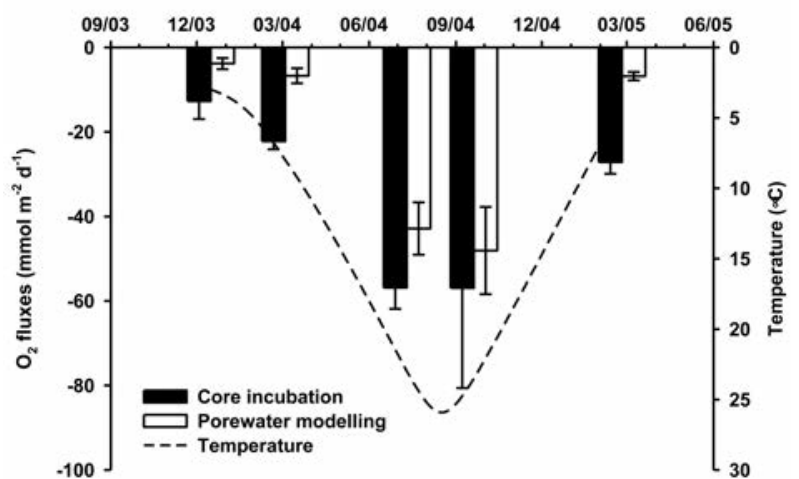

Fig. 4. Dark sediment oxygen demand measured via intact core incubation and calculated from porewater profiles. Average val$\mathrm{ues} \pm \mathrm{SD}(\mathrm{n}=3)$ are reported.

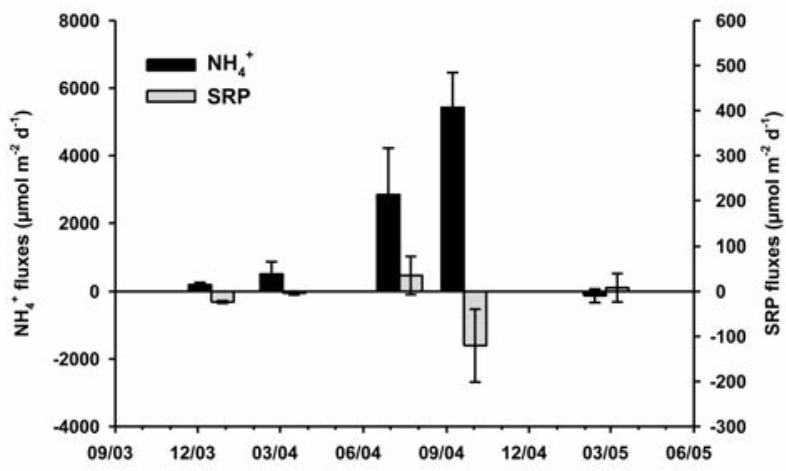

Fig. 5. Ammonium $\left(\mathrm{NH}_{4}^{+}\right)$and soluble reactive phosphorous (SRP) exchanges across the sediment-water interface measured via intact core incubation. Average values $\pm S D(n=3)$ are reported. 
most of the sediment profiles, which were homogeneous along the investigated horizon in all sampling periods.

Oxygen penetration at the sampling site was limited to a few millimetres depth and it was regulated by water temperature and bacterial activity. Below the oxic layer, strictly anaerobic metabolism probably driven by methanogenesis was coupled to very low Eh values; methanogenesis and gas ebullition contributes to sediment mixing (Segers, 1998; Liikanen et al., 2003; Longhi et al., 2008).

\section{Benthic fluxes in unconsolidated sediments}

Total oxygen uptake rates were comparable to those reported for other organic-rich freshwater sediments (Sweerts et al., 1991b; Fisher and Reddy, 2001). Oxygen uptake in whole core incubation exceeded that calculated from microprofiles as it includes respiration by plankton, bacteria, meio- and macrofauna, while diffusive fluxes account for microbial respiration alone (van Der Loeff et al., 1984; Aller, 1988; Archer and Devol, 1992; Glud et al., 1994). Maximum differences between oxygen fluxes from core incubations and microprofiling were calculated for winter months when macrofauna was limited to a few chironomids larvae. No information is available for meiofauna abundance in these sediments and meiofauna has the potential for high respiration rates (Lasserre et al., 1976).

Besides the presence of biota, several other factors could influence oxygen flux measurements in core incubation. For example, oxygen respiration in core incubations can overestimate in situ oxygen demand when stirring is too vigorous (Fisher and Reddy, 2001) and this could be the case at our sampling station, where water is generally stagnant. We suggest that rates measured via core incubations and calculated from micro profiles mod-

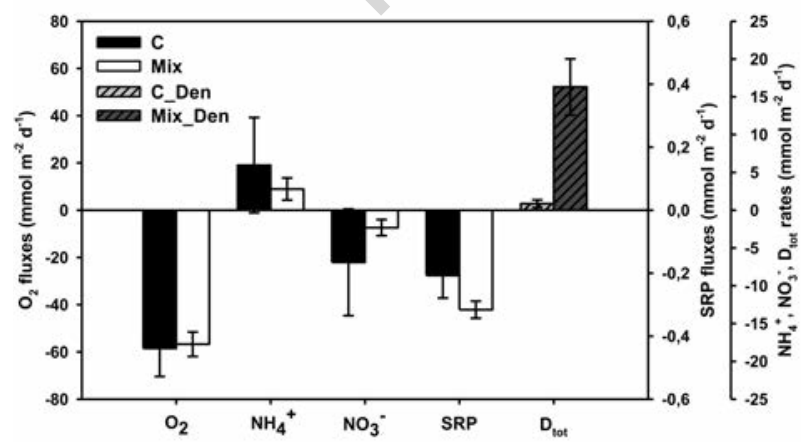

Fig. 6. Oxygen $\left(\mathrm{O}_{2}\right)$, ammonium $\left(\mathrm{NH}_{4}^{+}\right)$, nitrate $\left(\mathrm{NO}_{3}\right)$ and soluble reactive phosphorous (SRP) fluxes across the sedimentwater interface and denitrification rates $\left(D_{\text {tot }}\right)$ measured in control cores (C and C_Den) and in cores where sediments were resuspended (Mix and Mix_Den, see text for major details). Average values $\pm \operatorname{SD}(n=3)$ are reported. elling set the upper and lower limits of the true oxygen demand for these sediments, respectively.

On an annual basis, the net exchange of $\mathrm{NH}_{4}{ }^{+}$and SRP across the sediment-water interface was estimated in $\sim 750 \mathrm{mmol} \mathrm{NH}_{4}^{+} \mathrm{m}^{-2} \mathrm{y}^{-1}$ and $\sim-9 \mathrm{mmol} \mathrm{SRP} \mathrm{m}{ }^{-2} \mathrm{y}^{-1}$, suggesting that Busatello sediments were a net $\mathrm{N}$ source and a net $\mathrm{P}$ sink.

The flux of $\mathrm{NH}_{4}^{+}$calculated from porewater modelling was approximately 5 times lower than that calculated from core incubation and did not follow a seasonal pattern. This is an unexpected result since mineralisation rates and accumulation of solutes in interstitial waters are generally correlated to water temperature (Rysgaard et al., 1995; Clavero et al., 2000). The failure of diffusive fluxes to mirror expected seasonal patterns can be a consequence of porewater profiles vertical resolution. The resolution we adopted for sediment slices close to the interface $(1 \mathrm{~cm})$ is probably not accurate enough to record all the processes occurring at the sediment surface (Urban et al., 1997), but it was a consequence of sediments at sampling site, more comparable to an aqueous slurry than to a hard bottom. Besides spatial resolution, several other factors could influence the interpretation of porewater profiles. The fitting methodology of porewater profiles assumes that molecular diffusion is the most important transport process in the sediments and that steady-state conditions are present; but within the considered fluffy sediments the steady-state of porewater solutes is probably difficult to establish. We hypothesise that resuspension events may occur frequently enough to keep the sediments constantly mixed, in particular during summer months when faunal activity peak and ebullition phenomena are frequent. This hypothesis is in agreement with the lack of seasonal trends in nutrient porewater profiles and could explain differences between measured and calculated nutrient fluxes. This was not the same in the case of oxygen as oxygen penetration decreased by a factor 3 from winter to summer. It is likely that, after events of sediment resuspension, oxygen profiles reach a steady-state in a very short time lag, due to its rapid consumption in deep horizon (Gerhardt and Schink, 2005). The situation is probably different for solutes like $\mathrm{NH}_{4}{ }^{+}$and SRP, which are end products of mineralisation processes and enter into a number of both microbially-mediated and geochemical reactions. For these solutes the establishment of steady-state sedimentary profiles can require a longer time lag as it could be susceptible to factors like the vertical re-distribution of fresh and old organic matter, the development of specialised, slow-growing bacterial communities (i.e., nitrifiers) or the regeneration of biogeochemical buffers (i.e., $\mathrm{Fe}^{3+}$ pools). This could also explain the discrepancies observed between $\mathrm{NH}_{4}{ }^{+}$and SRP fluxes measured via incubation and calculated from porewater concentrations. In this organic rich bottom, SRP dynamics are probably influenced by adsorption processes to dissolved organic molecules which make interpretation 
of profiles complicated (Reddy et al., 1999). To conclude, we believe that nutrient fluxes calculated from porewater profiles are not reliable due to insufficient vertical resolution close to the interface and absence of steady-state gradients between the water column and the porewater from the upper sediment layers.

\section{Is sediment resuspension relevant for benthic fluxes and denitrification rates?}

Results from this experiment indicate: i) an instantaneous release of $\mathrm{NH}_{4}{ }^{+}$and SRP from porewater to the water column and a rapid consumption of $\mathrm{O}_{2}$ and $\mathrm{NO}_{3}^{-}$; ii) that resuspension and mixing of recalcitrant macrophytic litter did not affect significantly benthic fluxes and iii) that denitrification rates underwent a significant transient increase as a consequence of sediment resuspension. Ammonium and reactive phosphorus release following sediment mixing averaged $9.0 \pm 2.6 \mathrm{mmol} \mathrm{m} \mathrm{m}^{-2}$ and $41.6 \pm 38.3 \mu \mathrm{mol} \mathrm{m}{ }^{-2}$, respectively, and were approximately 20 and 16 times higher than daily fluxes measured via core incubations, respectively. This means that nutrient release during a single resuspension event was equivalent to the regeneration of $\mathrm{N}$ and $\mathrm{P}$ occurring in 2-3 weeks. However, sediment-water fluxes of $\mathrm{NH}_{4}{ }^{+}$were roughly counterbalanced by nitrate consumption rates, indicating that nitrogen production and consumption processes were in equilibrium.

The instantaneous decrease in water column oxygen and nitrate concentrations due to resuspension is partly due to dilution of overlying oxygenated water with anoxic porewater, and partly due to oxidation of reduced end products of mineralisation. These amounts were calculated knowing oxygen and nitrate concentrations in water column before and immediately after sediment mixing and the total volume of porewater. About 65 and $71 \%$ of oxygen and nitrate decrease was due to dilution, respectively, while about 35 and $29 \%$ was due to chemical consumption. If we assume the occurrence of one resuspension event per day, the overall oxygen consumption during the event accounts for $55 \%$ of total daily oxygen demand by sediments, as measured with intact cores incubations. This result is in agreement with those found by Adams et al. (1982) and Sweerts et al. (1991a), which have estimated the oxygen equivalents necessary for the oxidation of reduced inorganic compounds $\left(\mathrm{NH}_{4}{ }^{+}, \mathrm{Fe}^{2+}\right.$, $\mathrm{Mn}^{2+}, \mathrm{HS}^{-}$and $\mathrm{CH}_{4}$ ) in lake sediments. Adams et al. (1982) calculated that the oxidation of these compounds at the sediment-water interface was equivalent to $35 \%$ of the sediment oxygen demand, while Sweerts et al. (1991a) calculated that the oxidation of anoxic mineralisation end products accounted for up to $70 \%$ of the sediment oxygen consumption.

The significant stimulation of $\mathrm{D}_{\text {tot }}$ by resuspension is a consequence of $\mathrm{NO}_{3}{ }^{-}$transport within reduced pore- waters. When resuspension occurs, the $\mathrm{NO}_{3}{ }^{-}$(and $\mathrm{O}_{2}$ ) in the overlying water are transported in relatively deep sediment horizons where they are not generally present. Here, nitrate can be rapidly converted into $\mathrm{N}_{2}$ or $\mathrm{NH}_{4}{ }^{+}$, while oxygen can stimulate nitrification-coupled denitrification (Rysgaard et al., 1995). After the exhaustion of the supplied $\mathrm{NO}_{3}^{-}$(and $\mathrm{O}_{2}$ ) we expect denitrification rates to be again regulated by the diffusion of nitrate from the water column and by nitrification within sediments and thus similar to those measured prior to sediment resuspension.

The whole effect of all these simultaneous processes - occurring in a relatively short time lag - is probably to enhance the rates of organic matter mineralisation.

\section{ACKNOWLEDGMENTS}

This research was supported by the LIFE project LIFE00NAT/IT/7161: "Paludi di Ostiglia: interventi di salvaguardia dell'avifauna prioritaria".

\section{REFERENCES}

Adams DD, Matisoff G, Snodgrass WJ, 1982. Flux of reduced chemical constituents $\left(\mathrm{Fe}^{2+}, \mathrm{Mn}^{2+}, \mathrm{NH}_{4}^{+}\right.$and $\left.\mathrm{CH}_{4}\right)$ and sediment oxygen demand in lake Erie. Hydrobiologia 9192:405-414.

Aller RC, 1980. Quantifying solute distributions in the bioturbated zone of marine sediments by defining an average microenvironment. Geochim. Cosmochim. Acta 44:19551966.

Aller RC, 1988. Benthic fauna and biogeochemical processes in marine sediments: The role of burrow structures, p. 301-338. In: T.H. Blackburn and J. Sørensen (eds.), Nitrogen Cycling in Coastal Marine Environments. John Wiley and Sons, Chichester.

A.P.H.A., 1981. Standard Methods for the Examination of Water and Wastewaters. American Public Health Association, Washington, USA.

Archer D, Devol A, 1992. Benthic oxygen fluxes on the Washington shelf and slope: A comparison of in situ microelectrode and chamber flux measurements. Limnol. Oceanogr. 37:614-629.

Aspila KI, Agemian H, Chau ASY, 1976. A semi-automated method for the determination of inorganic, organic and total phosphate in sediments. Analyst 101:187-197.

Berg P, Risgaard-petersen N, Rysgaard S, 1998. Interpretation of measured concentration profiles in sediment pore water. Limnol. Oceanogr. 43:1500-1510.

Berner RA, 1980. Early diagenesis: a theoretical approach. Princeton University Press, Princeton, NJ, USA.

Blackburn TH, Henriksen K, 1983. Nitrogen cycling in different types of sediments from Danish waters. Limnol. Oceanogr. 28:477-493.

Bloesch J, Burns NM, 1980. A critical review of sediment traps techniques. Schweiz. Z. Hydrol. 42:15-55.

Breukelaar AW, Lammens EHRR, Breteler JGPK, Tatrai I, 1994. Effects of benthivorous bream (Abramis-brama) and carp (Cyprinus-carpio) on sediment resuspension and concentra- 
tions of nutrients and chlorophyll-a. Freshwat. Biol. 32:113121.

Broecker WS, Peng T-H, 1974. Gas exchange rates between air and sea. Tellus 26:21-35.

Callender E, Hammond DE, 1982. Nutrient exchange across the sediment-water interface in the Potomac river estuary. Estuar. Coast. Shelf Sci. 15:395-413.

Clavero V, Izquierdo JJ, Fernández JA, Niell FX, 2000. Seasonal fluxes of phosphate and ammonium across the sedimentwater interface in a shallow small estuary (Palmones river, southern Spain). Mar. Ecol. Prog. Ser. 198:51-60.

Cline JM, East TL, Threlkeld ST, 1994. Fish interactions with the sediment-water interface. Hydrobiologia 275:301-311.

D'Angelo EM, Reddy KR, 1994a. Diagenesis of organic matter in a wetland receiving hypereutrophic lake water: I. Distribution of dissolved nutrients in the soil and water column. J. Environ. Qual. 23:928-936.

D’Angelo EM, Reddy KR, 1994b. Diagenesis of organic matter in a wetland receiving hypereutrophic lake water: II. Role of inorganic electron acceptors in nutrient release. J. Environ. Qual. 23:937-943.

Dalsgaard T, Nielsen LP, Brotas V, Viaroli P, Underwood GJC, Nedwell DB, Sundback K, Rysgaard S, Miles A, Bartoli M, Dong L, Thornton DCO, Ottosen LDM, Castaldelli G, Risgaard-Petersen N, 2000. Protocol handbook for NICE-Nitrogen Cycling in Estuaries: a project under the EU research programme. Marine Science and Technology (MAST III). National Environmental Research Institute, Silkeborg, Denmark.

den Heyer C, Kalfs J, 1998. Organic matter mineralization rates in sediments: A within- and among-lake study. Limnol. Oceanogr. 43:695-705.

Emerson S, 1976. Early diagenesis in anaerobic lake sediments: chemical equilibria in interstitial waters. Geochim. Cosmochim. Acta 40:925-934.

Evans RD, 1994. Empirical evidence of the importance of sediment resuspension in lakes. Hydrobiologia 284:5-12.

Fisher MM, Reddy KR, 2001. Phosphorus Flux from Wetland Soils Affected by Long-Term Nutrient Loading. J. Environ. Qual. 30:261-271.

Froelich PN, Klinkhammer GP, Bender ML, Luedtke NA, Heath GR, Cullen D, Dauphin P, Hammond D, Hartman B, Maynard V, 1979. Early oxidation of organic matter in pelagic sediments of the eastern equatorial Atlantic: suboxic diagenesis. Geochim. Cosmochim. Acta 43:1075-1090.

Gerhardt S, Schink B, 2005. Redox changes of iron caused by erosion, resuspension and sedimentation in littoral sediment of a freshwater lake. Biogeochemistry 74:341-356.

Glud RN, Gundersen JK, Jorgensen BB, Revsbech NP, Schulz HD, 1994. Diffusive and total oxygen uptake of deep-sea sediments in the eastern South Atlantic Ocean: in situ and laboratory measurements. Deep-Sea Res. 41:1767-1788.

Glud RN, Holby O, Hoffmann F, Canfield DE, 1998. Benthic mineralization and exchange in Arctic sediments (Svalbard, Norway). Mar. Ecol. Prog. Ser. 173:237-251.

Godshalk GL, Wetzel RG, 1978. Decomposition in the littoral zone of lakes, p. 131-143. In: R.E. Good, D.F. Whigham, R.L. Simpson (eds.), Freshwater wetlands: Ecological processes and management potential. Academic Press, New York.

Haeckel M, Boudreau BP, Wallmann K, 2007. Bubble-induced porewater mixing: A 3-D model for deep porewater irrigation. Geochim. Cosmochim. Acta 71:5135-5154.

Hopkinson CS, Wetzel RL, 1982. In situ Measurements of Nutrient and Oxygen Fluxes in a Coastal Marine Benthic Community. Mar. Ecol. Prog. Ser. 10:29-35.

Jensen HS, Andersen FO, 1992. Importance of temperature, nitrate, and $\mathrm{pH}$ for phosphate release from aerobic sediments of four shallow, eutrophic lakes. Limnol. Oceanogr. 37:577589.

Jimenez-Montealegre R, Verdegem M, Zamora JE, Verreth J, 2002. Organic matter sedimentation and resuspension in tilapia (Oreochromis niloticus) ponds during a production cycle. Aquacult. Eng. 26:1-12.

Jørgensen BB, Glud RN, Holby O, 2005. Oxygen distribution and bioirrigation in Arctic fjord sediments (Svalbard, Barents Sea). Mar. Ecol. Prog. Ser. 292:85-95.

Klump JV, Martens CS, 1981. Biogeochemical cycling in an organic rich coastal marine basin-II. Nutrient sediment-water exchange processes. Geochim. Cosmochim. Acta 45:101105.

Koroleff F, 1970. Direct determination of ammonia in natural waters as indophenol blue, p. 19-22. In: Information on Techniques and Methods for Seawater Analysis. International Council for the Exploration of the Sea, Charlottenlund.

Kristensen E, 1985. Oxygen and inorganic nitrogen exchange in a Nereis virens (Polychaeta) bioturbated sediment-water system. J. Coast. Res. 1:109-116.

Lasserre P, Renaud-Mornant J, Caste LJ, 1976. Metabolic activities of meiofaunal communities in a semi-enclosed lagoon. Possibilities of trophic competition between meiofauna and mugilid fish, p. 393-414. In: G. Persoone, E. Jaspers, (eds.), $10^{\text {th }}$ Marine Biology Symposium. Universa Press, Wetteren.

Li Y, Gregory S, 1974. Diffusion of ions in sea water and in deep-sea sediments. Geochim. Cosmochim. Acta 38:703714.

Liikanen A, Huttunen JT, Murtoniemi T, Tanskanen H, Vaisanen T, Silvola J, Alm J, Martikainen PJ, 2003. Spatial and seasonal variation in greenhouse gas and nutrient dynamics and their interactions in the sediments of a boreal eutrophic lake. Biogeochemistry 65:83-103.

Longhi D, Bartoli M, Viaroli P, 2008. Decomposition of four macrophytes in wetland sediments: Organic matter and nutrient decay and associated benthic processes. Aquat. Bot. 89:303-310.

Mayer T, Ptacek C, Zanini L, 1999. Sediments as a source of nutrients to hypereutrophic marshes of Point Pelee, Ontario, Canada. Water Res. 33:1460-1470.

Moore PA, Reddy KR, Fisher MM, 1998. Phosphorus flux between sediment and overlying water in lake Okeechobee, Florida: Spatial and temporal variations. J. Environ. Qual. 26:1428-1439.

Nielsen LP, 1992. Denitrification in sediment determined from nitrogen isotope pairing. FEMS Microbiol. Ecol. 86:357362.

Niemisto J, Holmroos H, Pekcan-Hekim Z, Horppila J, 2008. Interactions between sediment resuspension and sediment quality decrease the TN:TP ratio in a shallow lake. Limnol. Oceanogr. 53:2407-2415.

Nurminen L, Horppila J, 2009. Life form dependent impacts of 
macrophyte vegetation on the ratio of resuspended nutrients. Water Res. 43:3217-3226.

Persson A, Svensson JM, 2006. Effects of benthivorous fish on biogeochemical processes in lake sediments. Freshwat. Biol. 51:1298-1309.

Pierobon E, Bolpagni R, Bartoli M, Viaroli P, 2010. Net primary production and seasonal $\mathrm{CO} 2$ and $\mathrm{CH} 4$ fluxes in a Trapa natans L. meadow. J. Limnol. 69:225-234.

Rabouille C, Denis L, Dedieu K, Stora G, Lansard B, Grenz C, 2003. Oxygen demand in coastal marine sediments: comparing in situ microelectrodes and laboratory core incubations. J. Exp. Mar. Biol. Ecol. 285-286:49-69.

Rasmussen H, Jorgensen BB, 1992. Microelectrode studies of seasonal oxygen uptake in a coastal sediment: role of molecular diffusion. Mar. Ecol. Prog. Ser. 81:289-303.

Reddy KR, D'Angelo EM, 1994. Soil processes regulating water quality in wetlands, p. 309-333. In: W.J. Mitsch (ed.). Global Wetlands: old world and new. Elsevier, Amsterdam.

Reddy KR, Fisher MM, Ivanoff D, 1996. Resuspension and diffusive flux of nitrogen and phosphorus in a hypereutrophic lake. J. Environ. Qual. 25:363-371.

Reddy KR, Kadlec RH, Flaig E, Gale PM, 1999. Phosphorus Retention in Streams and Wetlands: A Review. Critical Reviews in Environmental Science and Technology, 29:83-146.

Revsbech NP, 1983. In situ measurement of oxygen profiles of sediments by use of oxygen microelectrodes, p. 265-273. In: E. Graigner, H. Forstener (eds.), Polarographic oxygen sensors: aquatic and physiological applications. Springer, Heidelberg.

Rizzo WM, Lackey GJ, Christian RR, 1992. Significance of euphotic, subtidal sediments to oxygen and nutrient cycling in a temperate estuary. Mar. Ecol. Prog. Ser. 86:51-61.

Rowe GT, Clifford CH, Smith KL, Hamilton PL, 1975. Benthic nutrient regeneration and its coupling to primary productivity in coastal waters. Nature 255:215-217.

Rysgaard S, Christensen PB, Nielsen LP, 1995. Seasonal variation in nitrification and denitrification in estuarine sediment colonized by benthic microalgae and bioturbating infauna. Mar. Ecol. Prog. Ser. 126:111-121.
Scheffer M, 1998. Ecology of shallow lakes. Chapman and Hall, London.

Segers R, 1998. Methane production and methane consumption: a review of processes underlying wetland methane fluxes. Biogeochemistry 41:23-51.

Sondergaard M, Kristensen P, Jeppesen E, 1992. Phosphorus release from resuspended sediment in the shallow and windexposed lake Arreso, Denmark. Hydrobiologia 228:91-99.

Soto-Jimenez MF, Paez-Osuna F, Bojorquez-Leyva H, 2003. Nutrient cycling at the sediment-water interface and in sediments at Chiricahueto marsh: a subtropical ecosystem associated with agricultural land uses. Water Res. 37:719-728.

Sundback K, Enoksson V, Graneli W, Pettersson K, 1991. Influence of sublittoral microphytobenthos on the oxygen and nutrient flux between sediment and water: a laboratory continuous-flow study. Mar. Ecol. Prog. Ser. 74:263-279.

Sweerts J.-PRA, Bar-Gilissen M-J, Cornelese AA, Cappenberg TE, 1991a. Oxygen-consuming processes at the profundal and littoral sediment-water interface of a small meso-eutrophic lake (lake Vechten, The Netherlands). Limnol. Oceanogr. 36:1124-1133.

Sweerts J.-PRA, Kelly CA, Rudd JWM, Hesslein R, Cappenberg TE, 1991b. Similarity of whole-sediment molecular diffusion coefficients in freshwater sediments of low and high porosity. Limnol. Oceanogr. 36:335-342.

Urban NR, Dinkel C, Wehrli B, 1997. Solute transfer across the sediment surface of a eutrophic lake.1. Porewater profiles from dialysis samplers. Aquat. Sci. 59:1-25.

Valderrama JC, 1977. Methods used by the Hydrographic Department of National Board of Fisheries, Sweden, p. 13-40. In: K. Grasshof (ed.), Report of the Baltic Intercalibration Workshop. Interim Commission for the Protection of the Environment of the Baltic Sea, Annex.

van Der Loeff RMM, Anderson LG, Hall POJ, Iverfeldt A, Josefson AB, Sundby B, Westerlund SFG, 1984. The asphyxiation technique: An approach to distinguishing between molecular diffusion and biologically mediated transport at the sediment-water interface. Limnol. Oceanogr. 29:675-686. 